\title{
Wojciech Kozłowski, The Thirteenth-century Inter-Lordy System. Lordy Identity and the Origins of the Angevin-Piast Dynastic Alliance, Solivagus-Verlag, Kiel 2020, ss. 439
}

W swojej książce pt. The Thirteenth-century Inter-Lordy System. Lordy Identity and the Origins of the Angevin-Piast Dynastic Alliance Wojciech Kozłowski podjął próbę alternatywnego podejścia do polityki średniowiecznej. Jest to pewnego rodzaju studium przypadku na przykładzie analizy przyczyn małżeństwa dynastycznego zawartego między Andegawenami i Piastami w 1320 r. Autor wykorzystał techniki badań w zakresie IR (stosunków międzynarodowych) w odniesieniu do realiów średniowiecznych.

Praca składa się z pięciu rozdziałów, podzielonych na podrozdziały. Rozdział pierwszy poświęcony został teoriom dotyczącym międzynarodowych relacji w XIII w. W drugim odniesiono się do struktury systemu powiązań możnowładczych i powiązań między władcami w XIII-wiecznym świecie zachodnio-chrześcijańskim. W trzecim rozdziale autor poruszył kwestię systemu powiązań na przykładzie Władysława Łokietka w latach 1260-1300, zaś w rozdziale czwartym uczynił to w odniesieniu do Karola I Roberta (w latach 1300-1310). Rozdział piąty - finalny - poświęcony został genezie mariażu dynastycznego między Piastami i Andegawenami.

Wojciech Kozłowski na początku pracy zauważył, że wartość badań historycznych jest wypadkową dostępności źródeł i postawy samego historyka, który wybiera różne sposoby i przestrzenie badawcze. Wskazał, że pewne sposoby myślenia o polityce, w zakresie politologii, mogą być przydatne $\mathrm{w}$ interpretacji zjawisk politycznych $\mathrm{w}$ średniowieczu. Jest to ciekawe spostrzeżenie, które na wstępie zachęca do przeczytania książki.

W opinii W. Kozłowskiego nauki polityczne dysponują wypracowanym arsenałem pojęciowym i koncepcyjnym, pozwalając powiększyć kwestionariusz badawczy historyka. W jego ujęciu problemu teoria stosunków międzynarodowych pozwala stawiać pytania o wartości dominujące w polityce światowej w kontekście kulturowym łacińskiej Christianitas, pytać o motywacje uczestników wydarzeń oraz o zasady interakcji między uczestnikami wydarzeń (takimi jak monarchowie, książęta, władcy, papiestwo, cesarz itd.), a także strategie realizacji celów.

Istotne dla pracy jest pojęcie „lordship”. Autor pisze, że rozumie pod tym pojęciem zarówno terytoria pod kontrolą poszczególnych rycerzy oraz możnych (posiadłości, hrabstwa, niezależne miasta, księstwa, 
królestwa, włączając $\mathrm{w}$ to terytoria przynależne do papiestwa i cesarstwa), jak również domeny znajdujące się pod władzą elit kościelnych, to znaczy opatów, biskupów i arcybiskupów (s. 42), których miało być setki lub nawet tysiące. Owe władztwa traktuje jako najbardziej standardowe struktury władzy w XIII w. funkcjonujące jako grupy powiązanych przedstawicieli władzy różnego szczebla. Władztwa różniły się między sobą wielkością, bogactwem lub rangą. W XIII w. obserwuje się ich dzielenie, łączenie lub zanikanie. Istotne pojęcia w pracy to możnowładcza tożsamość czy współidentyfikacja, które służą badaczowi do określenia politycznych motywacji działań ludzi sprawujących władzę i cieszących się autorytetem.

W książce postawiono pytanie, jakie były przyczyny zawarcia w 1320 r. małżeństwa dynastycznego między Andegawenami i Piastami. Szeroko zostaje przedstawiony kontekst, w jakim zacieśniali swoją politykę Karol Robert i Władysław Łokietek w nawiązaniu do wydarzeń z XIII (a nawet XII) w., bowiem - jak zauważył autor - niemożliwe jest mówienie o systemie powiązań bez uwzględnienia analizy sytuacji międzynarodowej w dłuższej perspektywie czasowej. Autor zatem stawia pytanie, jak kształtowała się XIII-wieczna polityka powiązań i co determinowało narodziny sojuszu Karol Robert-Władysław Łokietek.

Przeprowadzając analizę sytuacji w XIII w., badacz zestawia pojęcia hierarchii i anarchii. Zastanawia się, czy anarchia zwyciężyła w XIII w. w systemie powiązań politycznych. W. Kozłowski wskazuje, że pozornie centralny system był spolaryzowany politycznie, ekonomicznie i militarnie. Przedmiotem badań autora jest hierarchia i anarchia we wzajemnym oddziaływaniu.

Przyglądając się systemowi hierarchii, W. Kozłowski zaczyna od analizy zakresu wpływów papieża, jako przywódcy świata chrześcijańskiego. Analizuje wpływ wywierany przez papieży: Bonifacego VIII, Innocentego III i Grzegorza IX na władców. Papieże w XIII w. podejmowali wiele akcji, które można widzieć jako interwencje w suwerenność państw, np. osadzali i obalali władców lub stawiali ich przed sądem. Robili to pod zarzutem naruszania zasad czy wolności Kościoła bądź przestępstw przeciw wierze i moralności. Badacz zauważa, że system powiązań politycznych został podporządkowany utrzymaniu wpływów w Ziemi Świętej. Papiestwo funkcjonowało na dwóch poziomach: jako gracz polityczny realizujący swoje interesy oraz najwyższy moralny autorytet. Siła autorytetu papiestwa zachęcała możnych do działania w papieskim interesie. Autor przygląda się także pozycji poszczególnych władców w ramach systemu hierarchii.

Jeden z podrozdziałów został poświęcony początkom książęcych władztw w Polsce. Władztwo w XIII w. postrzegane było jako oznaka 
wysokiego statusu. W XIII w. państwo piastowskie było rozbite na dzielnice. W opinii autora nie było miejsca na księcia określającego się jako „książę Polski” (s. 145), jednak można polemizować z tym stwierdzeniem, bowiem warto tutaj przypomnieć, co oznaczał ten termin w XIII w. Z jednej strony tak określali się książęta władający Wielkopolską, z drugiej tego tytułu używali jeszcze w I połowie XIII w. władcy mający pretensje do sprawowania władzy nad całym terytorium ziem polskich, np. Leszek Biały, a także, w legendzie na pieczęci, Konrad Mazowiecki.

Pojawiały się w omawianym czasie dwie przeciwstawne tendencje: dążenie do utrwalania podziału państwa albo przywrócenia jedności. Autor wskazuje, że tylko 3\% Piastów nie miało żadnych posiadłości (na Śląsku). Daje kilka ciekawych obserwacji w zakresie powiązań międzypiastowskich. Jak zauważa W. Kozłowski, na przestrzeni XII w. zaszły zmiany w odbieraniu władzy Piastów przez społeczeństwo, bowiem Anonim tzw. Gall określał Piastów jako domini naturales, przypominając o ich prawach do sprawowania władzy, ale już Mistrz Wincenty nie widział potrzeby podkreślania prawa Piastów do rządów, bowiem w jego czasach były one bezsporne. Przedstawiciele rodu Piastów myśleli o sobie jako godnych rządzenia już chociażby z urodzenia. Istotna była jednak wielkość władztwa, która decydowała o sile księcia. Zarówno w Polsce, jak i u sąsiadów w XIII w. obserwujemy okres intensywnego budowania władztw.

Autor dużą część pracy poświęcił analizie systemu powiązań w XIII w. Wskazał, że polityka powiązań księcia-ojca była ważnym punktem odniesienia dla zachowań syna. Badacz analizuje konflikty między Piastami w XIII w., kategoryzując je. Widoczne są dla niego powtarzające się wzorce, będące częścią politycznej kultury obszaru, na którym dochodziło do sygnalizowanych wydarzeń. W. Kozłowski definiuje konflikty na linii: ojciec-syn, wuj-bratanek, między braćmi oraz między Piastami $\mathrm{w}$ zakresie dalszego pokrewieństwa. Wskazuje, że powyższe konflikty nie działy się w politycznej próżni, angażując okoliczne możnowładztwo i rycerstwo. Historyk ten zauważa istotną rolę Krakowa i lokalnych możnych przyzwyczajających się do elekcyjnych wyborów w odniesieniu do władzy w Krakowie. W. Kozłowski podkreśla, że był tylko jeden przypadek, kiedy synowie otwarcie skonfrontowali się z ojcem, wskazując na Leszka Czarnego i Siemomysła, którzy wystąpili przeciwko Kazimierzowi kujawskiemu. Jednak, wydaje się, że to zbyt powierzchowne podejście, bowiem są przykłady trudnych relacji syna z ojcem - chociażby kwestia konfliktu Kazimierza kujawskiego z Konradem Mazowieckim. Autor wskazuje, że syn dziedziczył roszczenia i ogólny horyzont polityczny ojca. Omawiając politykę Henryka IV Probusa jako agresywną autor wskazuje, że Henryk szukał nowych dróg powiększania swego władztwa, 
tym samym kontynuując politykę swoich przodków: Henryka Brodatego i Henryka Pobożnego, którzy rządzili zarówno w Krakowie, jak i we Wrocławiu. Relacje między Wielkopolską i Śląskiem badacz traktuje jako wynik działalności Henryka Brodatego. Warto byłoby poruszyć tę kwestię w kontekście spuścizny Konrada I Mazowieckiego i kontynuacji polityki tego księcia przez jego potomków, do których należał przecież w prostej linii Władysław Łokietek. Autor daje też krótki przegląd relacji między braćmi i konfliktów w XIII w. Zauważa, że gdy bracia byli w stanie negocjować, były szanse do pokojowego współistnienia. Podkreśla, że międzybraterskie konflikty nie generowały wzajemnych zabójstw i licznych braterskich walk, choć podaje kilka przykładów bitew, jak Mozgawa, Suchodół, Bogucin czy Siewierz. Jednak nie jest do końca wyjaśniona kwestia śmierci niektórych książąt piastowskich. Poza tym W. Kozłowski jakby zapomina o silnych konfliktach potomków Konrada Mazowieckiego, występujących wzajemnie przeciw sobie przy wykorzystaniu posiłków ruskich bądź litewskich, np. Kazimierz kujawski i Siemowit; Konrad II czerski i Bolesław II płocki.

W. Kozłowski zwraca uwagę na kwestię wpływu sytuacji międzynarodowej na międzypiastowskie konflikty. Między 1239 a 1265 r. książęta Małopolski, Wielkopolski i Sieradza weszli w mariaże z Arpadami. Te małżeństwa zbliżyły ich do królestwa Węgier. Od około 1254 r. na sytuację na ziemiach polskich chciał mieć wpływ Przemysł Ottokar II, który zacieśniał relacje z książętami Śląska. Badacz wspomina wprawdzie o małżeństwach dynastycznych zawieranych przez córki Beli IV z książętami piastowskimi, ale możemy mieć wrażenie niedosytu, zwłaszcza w kontekście szukania przez niego genezy związku polsko-węgierskiego z początku XIV w. Brakuje choćby omówienia roli Gryfiny, zarówno w kontekście utrzymania porozumienia z Węgrami przez Leszka Czarnego, jak i z punktu widzenia roszczeń Wacława II do księstwa krakowsko-sandomierskiego. Kwestia roli i znaczenia małżeństw dynastycznych polsko-węgierskich lub polsko-czeskich, zawieranych w XIII w., wydaje się być potraktowaną zbyt pobieżnie, np. kwestia związku Bolesława płockiego z Kunegundą czeska, siostrą Wacława II wspomnianego przez W. Kozłowskiego w kontekście przejęcia władzy w Krakowie.

Celem autora staje się też szukanie wzorów rządzących konfliktami i wojnami oraz odpowiedź na pytanie, dlaczego konflikty narastały i jaki był wzór zachowań w przypadku ich zaistnienia. Autor wskazuje kilka grup konfliktów między Piastami. Jedną z głównych przyczyn walk była rywalizacja o Kraków. Badacz właściwie marginalnie wspomniał o rywalizacji książąt mazowieckich z kujawskimi. Brakuje też analizy wydarzeń w Cieni, np. w kontekście zdobycia tronu przez Władysława Laskonogiego. Znajdujemy wprawdzie w pracy wzmianki o roli niektórych możnych, 
np. przedstawicieli rodu Nałęczów w Wielkopolsce czy Piotra Włostowica, Jaksy bądź Klemensa z Ruszczy, a także Mikołaja Przedpełkowicza Łodzi z Wielkopolski czy dostojników kościelnych, np. biskupa kujawskiego Wolimira i biskupa krakowskiego Jana Muskaty, jednak brakuje rozważań o znaczeniu i roli krakowskiego możnowładztwa. Autor nie wymienia potężnych i wpływowych możnych, np. Pakosława Starego czy innych wojewodów krakowskich. Oni zaś używali np. tytulatury: „z Bożej łaski" lub formuły pluralis maiestaticus, bądź posługiwali się znakami napieczętnymi charakterystycznymi dla książąt. Odgrywali istotną rolę w ówczesnym systemie powiązań.

W przypadku analizy relacji między XIII-wiecznymi Piastami autor w minimalnym stopniu wykorzystuje wyniki prac historyków zajmujących się polityką poszczególnych książąt. Czytając tę książkę, szczególnie analizując przypisy, mamy wrażenie, że niewielu badaczy obecnie zajmuje się okresem tzw. rozbicia dzielnicowego. Głównie przedstawione w książce zostały konflikty na Śląsku. Zdecydowanie słabiej rozpatrywane są przez autora relacje na Mazowszu, między synami i wnukami Konrada Mazowieckiego, choć w opisie wydarzeń z przełomu lat osiemdziesiątych i dziewięćdziesiątych XIII w. W. Kozłowski wspomina nieco szerzej o dwóch koalicjach: śląskiej i kujawsko-mazowieckiej. W ostatnich czasach ukazały się liczne biografie wielu książąt: Leszka Białego, po dwie Konrada Mazowieckiego i Władysława Odonica czy Świętopełka gdańskiego, ponadto Siemowita, Bolesława II i książąt pomorskich, kujawskich, a także księżnych, np. Kingi. Autor nie przywołuje tych prac, co byłoby istotne dla przedstawienia stanu badań. W. Kozłowski nierzadko odwołuje się do ogólnych opracowań historii Polski, np. pisząc o polityce Swiętopełka gdańskiego. Nie uwzględniono artykułów także wielu innych badaczy zajmujących się np. kwestią stronnictw możnowładczych w okresie walk o władzę. Zrozumiałe jest, że przy syntetycznym ujęciu pomija się szczegółowe omawianie literatury, ale należałoby jednak zasygnalizować aktualny stan badań. Mamy ponadto odczucie nierównego przedstawienia sytuacji na ziemiach polskich, lepiej przedstawiane są systemy powiązań na przykładzie Wielkopolski i Sląska niż Małopolski, a precyzyjnie mówiąc księstwa krakowsko-sandomierskiego, bo pod taką nazwą Małopolska występuje w XIII-wiecznych źródłach. Jako zarzut w stosunku do autora można wskazać marginalne potraktowanie Mazowsza. Czasami odnosimy wrażenie, że autor patrzy na wydarzenia na ziemiach polskich ze śląskiej i wielkopolskiej perspektywy.

Pisząc o konfliktach, dobrze byłoby częściej odwoływać się do informacji pochodzących bezpośrednio ze źródeł, np. o długotrwałym konflikcie braci Bolesława II i Konrada II znajdujemy sporo relacji w Kronice 
halicko-wołyńskiej. Czasami autor opiera się głównie na przekazie Jana Długosza, brakuje odwołań do starszych źródeł.

XIII w. został przedstawiony przez W. Kozłowskiego jako okres konfliktów i postępującej anarchii. Próbuje on zbadać strukturę międzynarodowego systemu powiązań, wskazać, jak zachowywali się poszczególni uczestnicy wydarzeń zarówno z punktu widzenia ich cech osobowych, jak i istniejącego systemu powiązań. Analiza konfliktów między Piastami ujawnia wzory ich zachowań oraz sposoby zarządzania konfliktami. Konkluzja autora dotyczy hybrydowego systemu powiązań anarchii i hierarchii, z dominującym systemem anarchicznym. To staje się punktem wyjścia refleksji o sytuacji na początku XIV w. Pod koniec XIII w. kościół i elity, których interesy ekonomiczne ucierpiały z powodu rozdrobnienia, szukały osoby, która byłaby w stanie ograniczyć anarchię i przywrócić pokój. Ewentualnie takiej osoby szukano we Władysławie Łokietku.

Autor stawia pytanie, co determinowało działania Władysława Łokietka? Zauważa, że książę ten skupił w swoim ręku Kujawy, wschodnią Wielkopolskę, Gdańsk, Sieradz, Łęczycę, co czyniło z niego znacznego gracza. Warto zastanowić się jednak, jak był postrzegany przez elity poszczególnych ziem, którymi władał. Czy rzeczywiście w 1290 r. Łokietek miał otrzymać silną legitymację do objęcia Sandomierza? Na ile silna była ta legitymacja? W przypadku Pomorza, które po utracie wprawdzie ponownie odzyskał, czy uważano go tutaj za skutecznego władcę? (kwestia konfliktu ze Święcami, działalności zakonu krzyżackiego w tym czasie).

W. Kozłowski w jednym z kolejnych rozdziałów stawia pytanie, w jakich okolicznościach Łokietek stał się graczem na skalę międzynarodową. Zakłada, że nauczył się działać zarówno przez obserwację, jak i bezpośredni udział w wydarzeniach, nauczył się grać pewne role. Ciekawym jest, jak na jego przykładzie obserwuje przebieg procesu socjalizacji politycznej. W opinii autora ważna jest obserwacja, jakie osobiste cechy kandydata dawały szansę objęcia sukcesji. W tym zakresie jego spostrzeżenia są interesujące. Wskazuje jako ważny moment w karierze Łokietka rok 1300. Wtedy 40-letni Łokietek znalazł się w sytuacji szlachetnie urodzonego bezdomnego, zagrożonego przez Przemyślidów i niepewną przyszłością. Jak zauważył W. Kozłowski, Władysław Łokietek musiał w sytuacji, w której się znalazł, szukać okazji do przywrócenia władzy lub zdobycia nowego władztwa i działać w myśl zasady: Lord had to remain lord (s. 154).

W kolejnym rozdziale W. Kozłowski omawia kryzys sukcesyjny w królestwie Węgier, który rozważa jako standardowy konflikt o legitymację władzy w chrześcijańskim świecie. Stawia kilka pytań o wypadki między 1301 a 1310 r. Śledzi drogę Wacława III i Karola Roberta do tronu Węgier, analizując także ich systemy powiązań, w przypadku Karola wskazując na działanie na jego rzecz papieża, legata i węgierskiego kościoła. 
Badacz wskazuje, że rok 1320 z polskiej perspektywy ma specjalne znaczenie. Doszło do koronacji Władysława Łokietka i powrotu państwa polskiego na międzynarodową arenę po dwóch wiekach rozbicia. Koronacja Łokietka, zdaniem autora, była kluczowa dla przyszłości obu królestw: Polski i Węgier. Jako zwrotny punkt traktuje zawarte pół roku później dynastyczne małżeństwo. Autor próbuje rozwikłać kontekst i warunki małżeństwa. Szuka konceptualnych narzędzi do zbadania i wyjaśnienia systemu powiązań Karola i Łokietka. Jego cel to zbadanie dobrze znanych faktów z innej perspektywy poprzez analizę XIII-wiecznego systemu interesów i zachowań możnych. Jednak z tej perspektywy zdecydowanie za mało jest $\mathrm{w}$ pracy informacji o systemie powiązań na poziomie możnowładców.

W. Kozłowski omawia mariaż piastowsko-andegaweński w świetle źródeł polskich i węgierskich. Zauważa, że źródła nie mówią dość wyraźnie o powodach kierujących Karolem Robertem i Władysławem Łokietkiem. Omawia też stan badań. Według niemieckich badań mariaż piastowsko-andegaweński był odpowiedzią przeciw dominacji zagranicznej polityki Jana Luksemburskiego, z czym autor się nie zgadza. W. Kozłowski zauważył, że w czeskiej i słowackiej literaturze istnieje tendencja do marginalizowania związku Piastów i Andegawenów, zaś w węgierskiej i polskiej nauce funkcjonuje tradycja przyjaźni i wspólnoty interesów. Według polskich badaczy istotny był też spór z Janem Luksemburskim. W świetle węgierskich badań Karol utrzymywał kontakty z Władysławem Łokietkiem od 1306 r. Mariaż andegaweńsko-piastowski przeciwstawiano koalicji Habsburgów i Luksemburgów. Relacje w Europie środkowej w 1320 r. układały się korzystnie dla Łokietka, poza tym pamiętano o bliskim pokrewieństwie żony Władysława Łokietka, Elżbiety, z węgierskim rodem Arpadów. W. Kozłowski podkreśla, że historia sojuszu piastowsko-andegaweńskiego to nie tylko fakty, ale przede wszystkim plany i przewidywania polityczne, które wpływały na kształt wzajemnych relacji. Pojawia się pytanie, dlaczego Karol Robert postawił właśnie na Władysława Łokietka. Przyczyny sojuszu badacz widzi we wspólnocie interesów Karola Roberta i Łokietka: walczyli o trony z Czechami przy wsparciu papiestwa, zawarli wspólny front przeciw Luksemburgom, istotna była także tradycja rodzinna. Jako ważną autor traktuje kwestię finansów, np. stawia pytanie: kto i jak finansował powrót Władysława Łokietka do Małopolski. Między 1304 a 1312 r. Łokietek odzyskał, odbudował i podtrzymał swoje władztwo, musiał zmierzyć się z pretensjami Przemyślidów i walką o tytuł królewski. Autor wskazuje też na interesy węgierskich możnych, np. Amadeja Abba, który wspierał Łokietka, a później wszedł w konflikt z Karolem, czy Máté Csáka z północno-wschodniej części Węgier. W 1301 r. zwolnił się tron węgierski, 
a w 1306 r. czeski i polski. Do głosu doszło też możnowładztwo (tak w Czechach, na Węgrzech, jak i w Polsce), z którym pretendent musiał omówić warunki objęcia władzy, zatem pojawiają się elementy elekcyjności tronu.

Ciekawe jest spojrzenie na przyczyny zawarcia porozumienia. Obaj władcy: Władysław Łokietek i Karol Robert mogli mieć podobne aspiracje. Zdaniem W. Kozłowskiego różnicą było to, że Władysław Łokietek zdobył szersze niż Karol Robert poparcie możnych. Karol Robert musiał stoczyć batalię z możnymi. Od 1316 r. nasiliły się kontakty między Karolem i Łokietkiem. Andegawenowie lobbowali za koronacją Łokietka. Karol nie potrzebował pomocy ze strony Łokietka, ale zaczęła ich łączyć wspólnota interesów. Współpraca mogła też przynieść stabilizację w regionie. Polityka Łokietka przed 1320 r. zawęziła się do dwóch zagadnień: zgody papieża na koronację oraz dążenia do poniesienia przez krzyżaków konsekwencji za zajęcie Pomorza. Ponadto Łokietek miał poczucie, że przeżył braci i innych członków rodziny ze strony Kazimierza Sprawiedliwego i w 1320 r. był w takim wieku, w jakim umierał jego dziadek Konrad Mazowiecki. Książę zatem mógł obawiać się śmierci, zaś jego następca liczył tylko dziesięć lat, więc sojusz miał zabezpieczyć przyszłość Kazimierza, jako szwagra Karola Roberta, w którego przypadku zawiódł plan oparty na mariażu z Luksemburgami, bowiem królowa węgierska Beatrycze zmarła przy porodzie. Karol Robert znał plany Władysława Łokietka odnośnie do koronacji i zapewne pomyślał o nowym układzie w centralnej Europie. Łokietek i Karol byli sąsiadami bez nakładających się roszczeń. Interesy Karola i Łokietka zaczęły ich zbliżać do siebie.

Interesujące $\mathrm{w}$ pracy są refleksje o środowiskowych kontekstach działań obu władców. Autor podejmuje dwie główne kwestie: kontekst i motywy zawarcia porozumienia oraz śledzi sieć powiązań, w której obaj władcy działali. Podjęto też próbę rozpoznania wpływów i znaczenia XIII-wiecznego systemu powiązań i definiowania przez możnych swojej roli.

Wśród mankamentów pracy należy wymienić powierzchowne potraktowanie omawianych wydarzeń $\mathrm{w}$ stosunku do wschodnich terytoriów polskich, np. Mazowsza. Ponadto na podstawie pracy można wyciągnąć wniosek, że wiele kwestii nie zostało opracowanych w polskiej historiografii, stan badań został bowiem przedstawiony w sposób wybiórczy. Brakuje też przy omawianiu niektórych zjawisk analizy wydarzeń w świetle źródeł. Czytelnik zapewne chciałby także otrzymać wnikliwszą analizę systemu powiązań na poziomie możnych, a nie tylko władców. Z drobniejszych uwag: autor zbyt często przytacza przesadnie długie fragmenty z prac innych badaczy. Widoczna jest pewna niekonsekwencja dotycząca przytaczania bądź nieprzytaczania w przypisach polskiej wersji cytatu. Ponadto często powtarzają się w pracy te same wątki. 
Jednak niewątpliwie książka stanowi ciekawą próbę wykorzystania $\mathrm{w}$ badaniach historycznych metod stosowanych w naukach politycznych. Autor wskazuje nowe przestrzenie dla analizy średniowiecznej polityki przez śledzenie systemu powiązań. Słusznym jest, że kładzie nacisk na ukazanie uczestników wydarzeń w ich własnym „,środowisku”, ze wskazaniem kontekstu, który warunkował ich działania, a który jednocześnie oni sami współtworzyli. Praca prezentuje ciekawe podejście do historii politycznej okresu średniowiecza i niewątpliwie warto się z nią zapoznać.

Agnieszka Teterycz-Puzio (Pomeranian University in Słupsk, Poland) https://orcid.org/0000-0003-1728-3062 E-mail: agnieszka.teterycz-puzio@apsl.edu.pl

\begin{tabular}{|c|c|c|c|c|}
\hline \multicolumn{5}{|c|}{ PUBLICATION INFO } \\
\hline I & UMCS & : & $\begin{array}{l}\text { e-ISSN: } 2449-8467 \\
\text { ISSN: } 2082-6060\end{array}$ & OPEN ACCESS \\
\hline \multicolumn{5}{|c|}{$\begin{array}{l}\text { THE AUTHOR'S ADDRESS: Agnieszka Teterycz-Puzio, the Institute of History of the Pomeranian University in } \\
\text { Słupsk, 22a Arciszewskiego Street, Słupsk 76-200, Poland }\end{array}$} \\
\hline \multicolumn{5}{|c|}{ SOURCE OF FUNDING: Statutory Research of the Institute of History of the Pomeranian University in Słupsk } \\
\hline $\begin{array}{l}\text { SUBMITTED } \\
2021.02 .08\end{array}$ & & $\begin{array}{l}\text { ACCEPTED: } \\
2021.04 .13\end{array}$ & $\begin{array}{l}\text { PUBLISHED ONLINE: } \\
\text { 2021.06.30 }\end{array}$ & (c) \\
\hline \multicolumn{3}{|c|}{$\begin{array}{l}\text { WEBSITE OF THE JOURNAL: } \\
\text { https://journals.umcs.pl/rh }\end{array}$} & $\begin{array}{l}\text { EDITORIAL } \\
\text { COMMITTEE E-mail: } \\
\text { reshistorica@umcs.pl }\end{array}$ & Crossref dol \\
\hline
\end{tabular}

